\title{
Historical Retrospective of Environmental Problems of Oil-Extracting Regions (On the Example of the Almetyevsk District of Tatarstan Republic in Russia in the Second Half of the XX century)
}

\author{
Alsu L. Mirzagitova ${ }^{1}$ \\ ${ }^{1}$ Kazan Federal University, Elabuga, Russia \\ Correspondence: Alsu L. Mirzagitova, Kazan Federal University, Kazanskaya street 89, Elabuga, Tatarstan \\ Republic, 423600, Russia.
}

Received: October 24, 2014 Accepted: December 3, 2014 Online Published: December 18, 2014

doi:10.5539/res.v7n1p52

URL: http://dx.doi.org/10.5539/res.v7n1p52

\begin{abstract}
Article is directed on identification of resistant interrelation of industrial development of the concrete territory and ecological consequences of this development. On examples of archival materials are disclosed sources of formation of negative impact on environment of Tatarstan Republic. As the leading approach to research of a problem is chosen the method of the retrospective analysis which allows to track extent of industrial impact on environment of the Almetyevsk oil area throughout the semicentennial period. Prerequisites of need of formation of environmental policy for the region come to light. As a result of research are made conclusions that development of productive forces in the region the long time was carried out without its ecological features. The serious aggravation of an ecological situation became a result of it. However it brought also to that, production during the planning and implementation of the activity began to rely on the principle of greening. Materials of this article can be useful to theoretical and practical justification of expediency of implementation of economic activity with a support on the principles nature and resource saving.
\end{abstract}

Keywords: ecological history, Tatarstan Republic, environment, oil production, environmental problems

\section{Introduction}

\subsection{Relevance of a Problem}

So far in historical literature are almost not studied sources and evolution of contradictions in system "the person - the nature", arisen during formation of new industrial centers. Relevance of a problem first of all, consists in it, which comprehensive analysis will allow to avoid many mistakes at the present stage.

\subsection{Explore Importance of the Problem}

The current state of environment, periodically arising local ecological crises in various regions of the world, and in Russia in particular, caused in society a great interest to studying of regularities of the biosphere and anthropogenic system of mankind. Now nobody doubts in direct dependence of health, a functional state and quality of human life from habitat, various conditions of a household and production activity. That bigger value gets providing a wide range of specialists of various profile with necessary data in these problems.

Obviously that sources of environmental problems are multifactorial. For the XX century under the influence of the objective and subjective reasons, natural resources were used by mankind proceeding from need of every possible development of economy. For Russia also the major was a question of ensuring defense capability. Was considered that natural resources are boundless, the state of environment is invariable therefore questions of their preservation weren't prime. It is enough to track dynamics of change of an ecological condition of the certain territory throughout a certain interval of time clearly to see rates of development of a problem

\subsection{Status of a Problem}

In the Russian historiography the problem "environmental problems of oil-extracting regions" remains undeveloped so far. Mentioned problem in a complex wasn't considered. However there are works investigating separate aspects of a problem.

The most serious contribution to development of a subject of formation of an oil complex in the Volga region 
region was made by L. A. Budkov and A. D. Budkova (Budkov \& Budkova, 1976) which considered various aspects of creation and development of new oil base of the Soviet Union- "The Second Baku". They opened the increased value of Ural-Volga region oil base in providing the country with oil and oil products.

Distinctive sign of overwhelming part of the publications which appeared in the 60-80th of the XX century was their historical and political orientation.

Since the beginning of the 90th of last century there was an opportunity more objectively to estimate history of oil branch of the USSR. One of the most significant and promising areas that have attracted the attention of researchers, was the theme of the oil factor in the industrialization of the Soviet Union (Igolkin, 2005).

It is necessary to allocate monograph of M. V. Slavkina (2007). In it the author revealed a many-sided role of an oil and gas complex in country life, there is tracked influence of growth of oil production on development of transport, construction, agriculture and defense capability of the country.

The results of studying of history of oil branch of the Soviet Union in the XX century were summed up in the collection of scientific works "Oil of the country of Councils. Problems of history of oil industry of the USSR (1917-1991)" (Alekperova, 2005). In it the leading domestic scientists presented researches on history of oil industry of the Soviet period. There are given estimates of development of branch last century.

Serious contribution to research of a problem of interrelation of formation and development of an oil complex of the Volga region and the developed ecological situation of the XX century is work of A.M. Kalimullin "Historical research of regional environmental problems" in which the author in detail opens environmental problems of industrially developed regions of Central Volga area including the Republic of Tatarstan (Kalimullin, 2006).

Thus, at all variety of literature of historical, historical-economic and popular scientific character still a gap of the Russian and regional historiography is the insufficient number of researches of history of interrelation of formation and development of an oil complex of the Volga region and developed ecological situations of the XX century.

\subsection{Research Hypothesis}

The place and role of the industry in an ecological perspective received quite inconsistent estimates in researches of scientists. Often it is considered or as a source of all evils, or as the only rescue before danger of environmental disaster (McEvoy, 1995). However often researchers extremely simplify understanding of a phenomenon of scientific and technical development in modern conditions. Equipment in itself and technology are neutral in the relation to the nature. Only this or that nature of their application, determined mainly by concrete historical forms of their use causes various according to the contents and an orientation of a consequence, among them and ecological. It is possible to avoid ecologically negative consequences of industrial production only in that case, when production is based on the principles the nature and resource-saving.

\section{Methodological Framework}

\subsection{Research Objective}

The purpose of the conducted research consists in attempt of historical consideration of the environmental problems which resulted from industrial development in the second half of the XX century of the leading industrial region of Russia-Tatarstan Republic. As task of research became disclosure of prerequisites of an aggravation of contradictions in system "the person - the industry-nature" on the example of the oil-extracting industry of the region.

\subsection{Research Methods}

For check of a hypothesis was used the complex of the theoretical methods complementing each other: the analysis of literature, standard, acts of the studied period, the analysis of materials of periodicals; method of the retrospective analysis.

The main theses of research are formulated on the basis of the analysis of a wide range of the archival documents characterizing activity of public authorities, etc. in the field of conservation, and also the sources characterizing a condition of environment of the region during the considered period.

\section{Results}

\subsection{Sources of Environmental Problems of the Almetyevsk Disctrict}

Already initially process of oil production needed rigid regulation and control of the correct use of natural resources, especially such as arable, pasturable and forest grounds, the implementation of other measures for 
protection from environmental pollution. But in the first 15-20 years since the beginning of large-scale oil production in Tatarstan, nature protection aspects were simply ignored because of an urgent need of oil for economy of the state.

We will stop on some aspects showing negligence to the organization of oil production on first time of development of oil in "the Romashkinsky" field.

So, for rational development of an oil field and its correct operation, it is necessary to carry out a complex of research works. The main part of them accounted for geological services oilfields. However, the research team needed even in the necessary equipment and devices. So, according to the report of the senior geologist of production field No. 2 V. Filanovsky, "on field not enough deep manometers, absolutely are absent piezographs (devices for definition of the content of gas in oil), etc." (Archival department of executive committee of Almetyevsk municipal district, 1954). Such circumstances caused impossibility to conduct technically competently researches of wells and layer. Often there were cases, when for research of this or that wellsite were wasted time, means, but due to the lack of reliable devices received incorrect data, that led to losses of tens tons of oil.

Other example. For various reasons, oil could get on the earth. In this case it needs to be collected from a surface into tanks, thereby having reduced its negative impact by an affected area. However, often field men only burned spilled oil. So the newspaper "Znamya Truda" specifies that on a well of "1229 second field was in this way destroyed 10 tons of liquid fuel" (Archival department of executive committee of Almetyevsk municipal district, 1958). Periodically there were fixed the facts when workers of crafts from open barns of wells took oil for the needs, thus they didn't use safety measures therefore oil got to trenches, holes. Often occurred in the wells accidents, which were accompanied by a loss of fuel. Accidents happened because of bad welding of pipes, weak control of their state, due to the lack of coherence between heads of the crafts and the enterprises which are engaged in a construction of trade objects. Eyewitnesses tell about oil modulation cases from flow tanks (Bagmanov, 2014).

The example of negligence of constructors is shown in "Znamya Truda" newspaper. Building contractor No. 4 lays the Almetyevsk-Verchny Aktash oil pipeline leaving behind essential subquality work. So, at the end of the oil pipeline the latch was put, and the cap was absent. In this place was cut in the 8-inch line, conducting to other wellsite. Wells did not have valves. When employees of construction group "Tatneftepromstroy" filled up a trench, on negligence filled up also a latch of the 8-inch line. At that time the well was repaired. After the end of repair the duty repairman Fadeyev mistakenly opened an oil pipeline latch, as couldn't find a latch of the 8-inch line. As the cap was absent, oil under pressure directed to the river Zai, flowing nearby. Coast throughout four kilometers were oil-contaminated, oil got to the river (Archival department of executive committee of Almetyevsk municipal district, 1958).

Along with pollution of atmospheric air, the enterprise of oil production caused and cause serious damage to water resources. One of types of such damage is pollution of the rivers and reservoirs as a result of dumping in them harmful substances. So, researches of 1964-1968 in oil-extracting areas showed that there, during the summer period the content of the weighed and soluble oil products in water was steady and made $5 \mathrm{mg} / \mathrm{l}$., raising to $15-70 \mathrm{mg} / \mathrm{l}$. in the period of rains, due to washout of the poured oil (Coates, 1991).

Now dynamics of the content of chlorides and oil products in the small rivers of the republic is already established. It testifies that in the 70-80th there was their steady increase that led to gradual pollution of a surface water which reached a maximum in 1986. However in the next years as the statistics testifies, situation began to improve (Phillips, 1999).

\subsection{The First Nature Protection Actions on Oil Fields of Almetyevsk}

Only in the 60th on oil fields of the republic were made first attempts of carrying out actions for improvement of rational use of natural resources. There began works on sealing of systems of collecting oil and gas, promoting preservation of light hydrocarbons of oil, i.e. reduction of the losses, allowing to reduce pollution of atmospheric air. For comparison it is necessary to specify, that in 1961 more than 1200 operational wells giving gas, weren't connected to gas-collecting networks. As a result of it, loss of associated gas, and respectively emissions in the atmosphere increased from year to year. The gas efficiency, making in 1960-60.6 percent, decreased in 1961 to 59 percent. In 1961 only on torches it was burned more than 1 billion cubic meters of associated gas, whereas the majority of the industrial enterprises of the republic had an acute shortage in fuel.

For reduction of pollution of atmospheric air and reduction of losses of light hydrocarbons, in "Tatneft" Production Association was carried out sealing of systems of collecting, transport, storage of oil and gas. Actions, 
begun in 1963-1964, allowed to expel from collecting system such knots as gauging tank, tanks of assembly points, points of pumping of oil which are a source of plentiful releases of gas. By the beginning of 1973 were pressurized 7095 wells, that made 80 percent from their total number.

In this regard, in the oil-extracting industry of Tatarstan were repeatedly made attempts actions directed, on the one hand, on reduction of consumption of fresh water for technological needs, and with another - on purification of the formed sewage. There was limited the ineffective and unproductive pumping water when flooding layers, for maintenance of reservoir pressure as much as possible tried to use oil-field sewage. So, if in 1965 in systems of flooding only 2 percent of sewage were utilized, in 1975-68.4 million cubic meters that made 73 percent. For their injection were changed over about 700 flow wells (Pisani, 2000).

For the maximum use of oil-field sewage, for the purpose of maintenance of reservoir pressure were constructed treatment facilities. Utilization in such way, partially solved a problem of rational use of resources of fresh water and at the same time almost completely eliminated a source of pollution of reservoirs. The order in "Tatneft" Production Association of 1976 "About strengthening of the nature and improvement of use of natural resources" provided by 1980 use of all volume of the formed sewage for maintenance of reservoir pressure. However implementation of this order was tightened for longer period.

Thus, the oil and gas extraction enterprises of Almetyevsk by the beginning of the 80th years developed the oil fields, occupying the space in 32 square kilometers. In operation there were thousands oil and service wells, tens thousands kilometers of pipelines of different function. All this, of course, imposed heavy responsibility on rational use and environmental protection. It was expressed in the whole complex of actions realized by "Tatneft" association.

\section{Discussions}

Tatarstan Republic entered in the XXI century with serious ecological heritage. Unfortunately, sources don't give to researchers the chance comprehensively to track process of industrial environmental pollution of the republic throughout the XX century. Such data often don't exist due to the lack of control of this process. Opportunities for this purpose appeared much later, in the 80th of the XX century. However on the basis of extremely rare archival materials and publications in periodicals, on the concrete facts nevertheless it is possible to track the separate reasons of a modern difficult ecological situation in Tatarstan.

Sources of the environmental problems peculiar to the territory Tatarstan Republic are multifactorial. For the XX century was considered that natural resources are boundless, the state of environment is invariable, therefore questions of their preservation weren't prime. It also caused deterioration of an ecological situation in industrial, especially in oil areas of the republic (Kalimullin, 2014). Despite absolute relevance of questions of ecological safety in oil branch for Almetyevsk district, researches in this field still weren't until the end of the XX century. It explains that fact, that environmental policy of branch was formed by a trial and error method. It is possible to give only single works of foreign researchers which open specifics of some technological aspects of oil production, consequences of various invasions of the person into a lithosphere which result are unpredictable processes - earthquakes, terrestrial failures, etc. (Black, 1998 allow to warn; Sabin, 1998; Quam-Wickham, 1998).

Scales and the sphere of destruction of environment continued to increase, methods and means of fight considerably became complicated. At the same time, thanks to opportunities of the nature to replicate, and also absence of services and the mechanism of control, low ecological consciousness of people, the nature protection problem wasn't particularly acute so, as now. Nevertheless, the first signs of the approaching crisis already started being felt.

It is known that a serious impulse to formation of industrial shifts in Tatarstan in the second half of the XX century, gave oil production. Development of oil fields, being rather difficult technological process, quite often was followed by consequences which are harmful for the nature. Oil production process as no type of the industry, is in a condition of close and continuous interaction with environment, negatively influencing on change of qualitative structure of its resources - the soil, water, vegetation and in general environment.

\section{Conclusion}

The extensive way of development of production, first of all, was reflected in consumer, and, often, and in the irresponsible relation to the organization of production. At bottom formed a strong interconnected triad: heavy industry-ecology-welfare. Industrial progress of Tatarstan was followed by receipt to the biosphere of a huge number of pollution which led to violation of natural balance and deterioration of human health, as since in an initial stage of development of this or that industry violations of all spheres of environment were almost allowed: 
pollution of land, forest, pasturable grounds, rivers and reservoirs, saturation of the atmosphere with combustion products, etc. In consciousness of people, their actions, in design decisions and construction plans of the enterprises reigned ecological illiteracy, abuses in use of natural vulnerability. As a result the significant damage was caused to environment. All this led to formation of the thought-over environmental policy of "Tatneft" Production Association, focused on: increase of industrial and ecological safety of hazardous production facilities due to ensuring reliable and trouble-free operation of processing equipment, introduction of effective methods of technical diagnostics of the equipment; identification, assessment and decrease of industrial dangers and risks; increase of efficiency of control of observance of requirements of industrial and ecological safety on production objects of the company; reduction of negative impact on environment due to introduction of new progressive technologies, equipment, materials and increase of level of automation of operation of technological processes; rational use of natural resources, minimization of losses of oil and gas.

\section{References}

Alekperova, V. Y. (2005). Oil of the country of Councils (p. 618). Problems of history of oil industry of USSR (1917-1991).

Bagmanov, R. G. (2014). Urgent question. From conversations with the driller of trade No. 2.

Black, B. (1998). Oil Creek as Industrial Apparatus: Re-creating the Industrial Process through the Landscape of Pennsylvania's Oil Boom. Environmental History, 3(2), 210-229. http://dx.doi.org/10.2307/3985380

Budkov, A. D., \& Budkov, L. A. (1976). To history of formation and development of the Second Baku. History USSR, 2, 108-117.

Igolkin, A. A. (2005). Oil policy of USSR in the 1928-1940 (p. 334).

Kalimullin, A. M. (2006). Historical research of regional environmental problems (p. 368).

Kalimullin, A. M. (2014). Stages of Ecological Policy Development in the Industrial Sector of Russia in the Second Half of the XXth Century: Historical Perspective. Life Science Journal, 11(8s), 492-497;

McEvoy, A. F. (1995). Working Environments: An Ecological Approach to Industrial Health and Safety. Technology and Culture, 36, 142-164. http://dx.doi.org/10.2307/3106693

Peter, A. (1991). Coates. The trans-Alaska Pipeline Controversy: Technology, Conservation, and the Frontier. Bethlehem, $\mathrm{Pa}$.

Phillips, C. A. (1999). Lessons from the dust bowl: Dryland Agriculture and Soil Erosion in the United States and South Africa, 1900-1950. Environmental History, 4(2), 245-266. http://dx.doi.org/10.2307/3985305

Pisani, D. J. (2000). Beyond the Hundredth Meridian: Nationalizing the History of Water in the United States. Environmental History, 5(4), 466-482. http://dx.doi.org/10.2307/3985582

Quam-Wickham, Ny. (1998).Cities Sacrificed on the Altar of Oil: Popular Opposition to Oil Development in 1920s Los Angeles. Environmental History, 3(2), 189-209. http://dx.doi.org/10.2307/3985379

Sabin, P. (1998). Searching for Middle Ground: Native Communities and Oil Extraction in the Northern Central Ecuadorian Amazon, 1967-1993. Environmental History, 3(2), 144-168. http://dx.doi.org/10.1093/envhis/3.2.144

Slavkina, M. B. (2007). Great victories and the missed opportunities: Influence of an oil and gas complex on social and economic development of USSR in 1945-1991 (p. 384).

\section{Copyrights}

Copyright for this article is retained by the author(s), with first publication rights granted to the journal. This is an open-access article distributed under the terms and conditions of the Creative Commons Attribution license (http://creativecommons.org/licenses/by/3.0/). 